\title{
Desain Dan Implementasi Hybrid Cloud Computing Sebagai Infrastruktur Untuk Analisis Big Data Menggunakan Analytic Hierarchy Process(AHP)
} Design and Implementation Of Hybrid Cloud Computing As Infrastructure For Big Data Analytics Using Analytic Hierarchy Process (AHP)

\author{
Toga Aldila Cinderatama ${ }^{1}$, Yoppy Yunhasnawa ${ }^{2}$, Rinanza Zulmy Alhamri ${ }^{3}$ \\ 1,3Program Studi Teknik Informatika Politeknik Kediri, Jalan Mayor Bismo 27, Kediri, \\ ${ }^{2}$ Jurusan Teknologi Informasi, Politeknik Negeri Malang, Jl. Soekarno Hatta No. 9 Malang \\ e-mail: ${ }^{1}$ togaaldila@poltek-kediri.ac.id, ${ }^{2}$ yunhasnawa@polinema.ac.id, ${ }^{3}$ rinanza.z.a@poltek- \\ kediri.ac.id
}

\begin{abstract}
Abstrak
Dalam implementasi big data dibutuhkan sumber daya yang cukup besar untuk dapat melakukan analisis terhadap data-data yang jumlahnya sangat besar tersebut, hal ini biasanya menjadi kendala dikarenakan keterbatasan sumber daya yang dimiliki. Komputasi awan (cloud computing) yang salah satunya mempunyai sifat elasticity di dalamnya, menawarkan solusi keterbatasan sumber daya ini. Sumber daya yang terbatas misalkan dalam hal processor, RAM atau storage, dapat digabungkan dengan sumber daya yang dimiliki public cloud provider yang tersedia di market. Sehingga penggabungan 2 sumber daya ini, private cloud dan public cloud, diharapkan menjadi solusi untuk dapat mengimplementasikan analisis big data yang dapat diterapkan untuk analisis berbagai macam bidang. Secara umum penelitian ini bertujuan untuk mengimplementasikan hybrid cloud yang menggabungkan sumber daya dari private cloud dengan sumber daya dari public cloud sebagai infrastruktur untuk analisis big data. Secara khusus tujuan penelitian ini adalah merumuskan sebuah metode minimalisasi cost dalam pemilihan public cloud dengan pendekatan sistem pendukung keputusan menggunakan metode AHP pada pemilihan public cloud. Langkah pertama yang dilakukan dalam penelitian ini adalah pengumpulan data cost penggunaan resource dari public cloud. Selanjutnya dilakukan analisis kebutuhan sumber daya yang diperlukan untuk melalukan analisis big data dengan studi kasus topik tertentu. Selanjutnya tahap analisis terhadap pemilihan public cloud yang tepat untuk digunakan sumber dayanya dengan pertimbangan minimalisasi cost. Langkah terakhir adalah implementasi hybrid cloud dan melakukan analisis dan evaluasi terhadap metode yang diusulkan.
\end{abstract}

Kata kunci- AHP, Cloud Computing, Hybrid Cloud Computing

\begin{abstract}
In the big data implementation required a large enough resources to be able to analyze the very large data, usually it is become a constraint due to the limitation of resources. Cloud computing offers a solution of this resource limitation. Limited resources such as in the case of processor, RAM or storage, can be combined with resources owned by public cloud providers available in the market. The combination of these two resources, private cloud and public cloud is expected to be a solution to implement big data analysis in various fields. In general, this study aims to implement a hybrid cloud that combines resources from a private cloud with the resources of the public cloud as an infrastructure for big data analysis. In particular the purpose of this study is to formulate a method of minimizing cost in the selection of public cloud with a decision support system approach using Analytic Hierarchy Process (AHP) in public cloud selection. The first step taken in this research is the collection of data cost of resource usage from the public cloud. Furthermore, the analysis of resource requirements required to big
\end{abstract}


data analysis with case studies of certain topics. The next phase of analysis of the appropriate public cloud selection for resource use with the consideration of minimization cost. The final step is to implement the hybrid cloud and perform analysis and evaluation of the proposed method.

Keywords - AHP, Cloud Computing, Hybrid Cloud Computing

\section{PENDAHULUAN}

Komputasi awan (cloud computing) dan analisis big data (big data analysis) saat ini merupakan teknologi yang tidak dipisahkan dalam dunia teknologi informasi. Pertumbuhan data yang eksponensial di berbagai macam bidang, contohnya pada bidang kesehatan, bidang ekonomi \& bisnis, atau bidang teknologi informasi sendiri pada akhirnya menuntut diterapkannya analisis big data sehingga dapat dihasilkan knowledge-knowledge baru dari data yang sudah ada. Dalam implementasi big data biasanya membutuhkan sumber daya yang cukup besar untuk dapat melakukan analisis terhadap data-data yang jumlahnya sangat besar tersebut, hal ini biasanya menjadi kendala dikarenakan keterbatasan sumber daya yang dimiliki. Komputasi awan (cloud computing) yang salah satunya mempunyai sifat elasticity di dalamnya, menawarkan solusi keterbatasan sumber daya ini. Sumber daya yang terbatas misalkan dalam hal processor, RAM atau storage, dapat digabungkan dengan sumber daya yang dimiliki public cloud provider yang tersedia di market. Sehingga penggabungan 2 sumber daya ini, private cloud dan public cloud, diharapkan menjadi solusi untuk dapat mengimplementasikan analisis big data yang dapat diterapkan untuk analisis berbagai macam bidang. Dalam menentukan public cloud yang terpilih tentunya diperlukan sebuah metode yang tepat. Salah satu metode yang dapat diterapkan adalah menerapkan system pendukung keputusan menggunakan AHP yang digunakan untuk menentukan bobot prioritas pada masing-masing kriteria penggunaan public cloud yang menjadi dasar untuk analisa keputusan yang tepat dalam memilih sumber daya dari public cloud.

Beberapa penelitian tentang penerapan cloud computing telah dilakukan yaitu implementasi server untuk sistem komputasi awan di intranet kampus Institut Teknologi Telkom dan dipilih aplikasi layanan word processing dimana client dapat membuat dokumen, mengubah ataupun meng-upload dokumen mereka dan akan tersimpan dalam storage server sehingga mengurangi beban kapasitas penyimpanan dokumen tersebut dalam harddisk pada device client[1]. Sedangkan penelitian tentang sistem pendukung keputusan menggunakan AHP telah dilakukan oleh banyak penulis diantara berupa website untuk memberikan rekomendasi properti di Kabupaten Buleleng yang dikembangkan diharapkan dapat membantu berbagai pihak dalam memberikan rekomendasi properti di Kabupaten Buleleng. Pada penelitian lain, dibuat perangkat lunak SPK yang dibangun dengan mengimplementasikan model AHP untuk menyelesaikan permasalahan pengambilan keputusan[2]. Pada metode AHP, permasalahan dimodelkan dalam sebuah hirarki dan ranking alternatif ditentukan berdasarkan prioritas. Prioritas dihitung berdasarkan nilai perbandingan berpasangan yang diberikan oleh decision maker pada setiap level hirarki[3]. Pada penelitian lainnya membahas tentang paradigma hybrid cloud computing sebagai solusi yang menjanjikan untuk Software-as-a-Service (SaaS) untuk mengerjakan request dari user yang selalu dinamis. Pada penelitian tersebut difokuskan bagaimana mengoptimasi operasional cost dari hybrid cloud untuk menyelesaikan problem biaya sewa public cloud yang belum tersedia informasi awalnya dan probabilitas kebutuhan request user yang akan datang dimana masih belum diketahui jumlahnya menggunakan Lyapunov optimization[4].

Dari uraian tersebut, pada penelitian ini pengusul ingin mengimplementasikan sebuah infrastruktur hybrid cloud[5][6] yang menggabungkan sumber daya dari server pribadi yang dimiliki (private cloud) dengan sumber daya dari public cloud dengan menggunakan AHP untuk minimalisasi cost sehingga dapat terpilih sumber daya yang paling efektif dan efisien untuk digunakan sebagai infrastruktur analisis big data. 


\section{METODE PENELITIAN}

Adapun langkah-langkah yang akan dilakukan pada penelitian ini dapat digambarkan seperti pada Gambar 1:

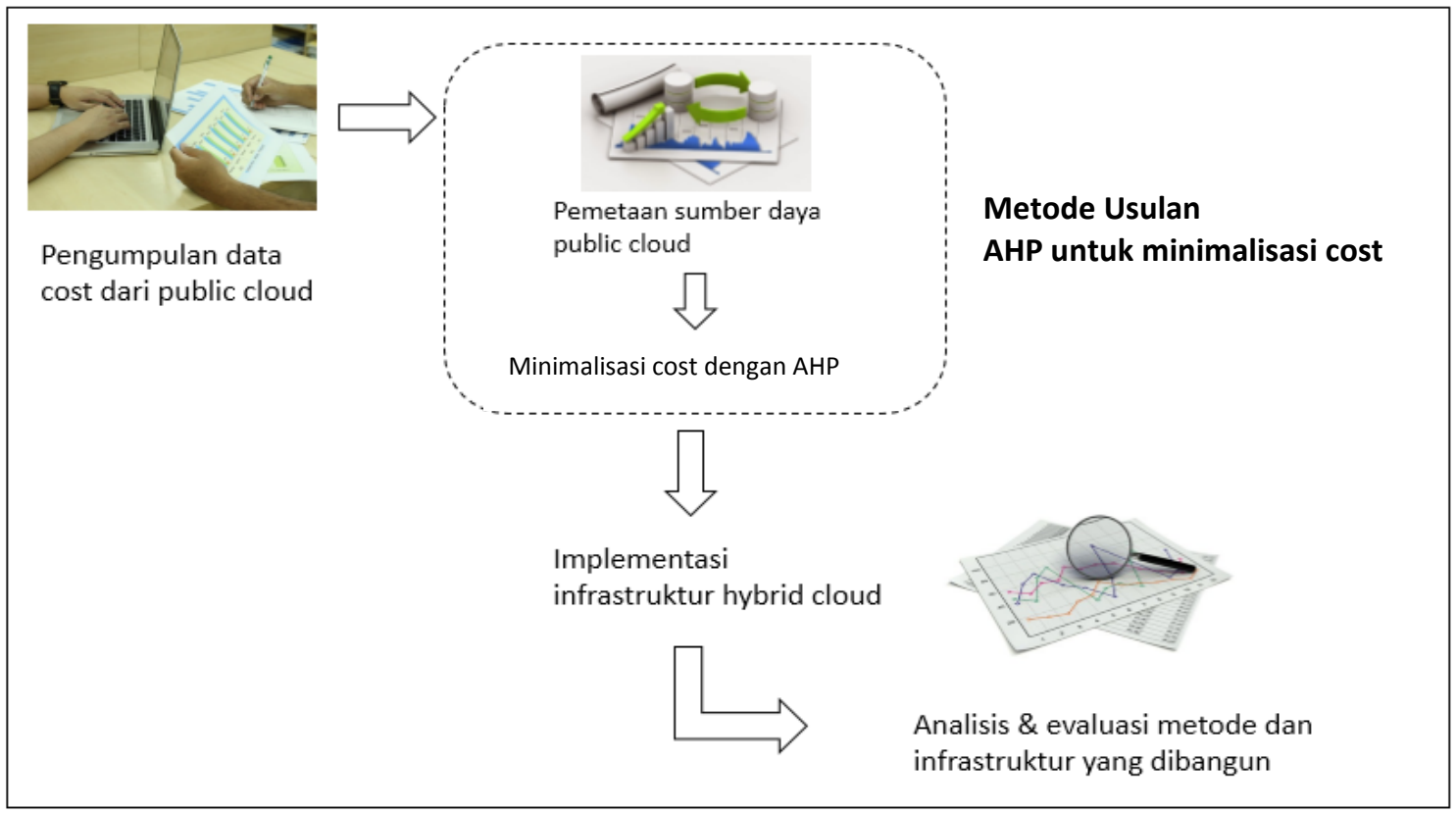

Gambar 1. Alur Penelitian

\subsection{Pengumpulan Data}

Data biaya public cloud diambil dari berbagai harga yang diterapkan oleh public cloud provider yang berbeda-beda. Data biaya diambil dari sekitar 10 public cloud provider yang tersedia di market, data yang dipertimbangkan adalah : spesifikasi CPU yang akan digunakan (core dan speed), spesifikasi RAM yang akan digunakan, spesifikasi storage yang akan digunakan, dan harga paket. Data tersebut dapat ditulis seperti pada Tabel 1

Tabel 1. Data Public Cloud Provider

\begin{tabular}{|c|c|c|c|c|c|}
\hline $\begin{array}{c}\text { Cloud } \\
\text { Provider }\end{array}$ & $\begin{array}{l}\text { CPU } \\
\text { core }\end{array}$ & $\begin{array}{c}\text { CPU } \\
\text { speed }\end{array}$ & RAM & $\begin{array}{c}\text { Stor } \\
\text { age }\end{array}$ & $\begin{array}{c}\text { Harga } \\
\text { Paket }\end{array}$ \\
\hline Cloud $_{11}$ & $\begin{array}{c}\text { CPU } \\
\operatorname{core}_{11}\end{array}$ & $\begin{array}{c}\text { CPU } \\
\text { speed }_{1}\end{array}$ & $R A M_{11}$ & $\begin{array}{c}H D_{1} \\
1\end{array}$ & $\boldsymbol{P r}_{11}$ \\
\hline Cloud $_{12}$ & $\begin{array}{c}C P U \\
\text { core }_{12}\end{array}$ & $\begin{array}{c}\text { CPU } \\
\text { speed }\end{array}$ & $R A M_{12}$ & $\begin{array}{c}H D_{1} \\
2\end{array}$ & $\boldsymbol{P r}_{12}$ \\
\hline Cloud $_{13}$ & $\begin{array}{c}\text { CPU } \\
\text { core }_{13}\end{array}$ & $\begin{array}{c}\text { CPU } \\
\text { speed }\end{array}$ & $R A M_{13}$ & $\begin{array}{c}H D_{1} \\
3\end{array}$ & $\boldsymbol{P r}_{13}$ \\
\hline$\cdots$ & $\ldots$ & $\ldots$ & $\ldots$ & $\ldots$ & $\cdots$ \\
\hline Cloud $_{21}$ & $\begin{array}{c}\text { CPU } \\
\text { core }_{21}\end{array}$ & $\begin{array}{c}C P U \\
\text { speed }\end{array}$ & $R A M_{21}$ & $\begin{array}{c}\mathrm{HD}_{2} \\
1\end{array}$ & $\boldsymbol{P r}_{21}$ \\
\hline Cloud $_{22}$ & $\begin{array}{c}C P U \\
\text { core }_{22}\end{array}$ & $\begin{array}{l}\text { CPU } \\
\text { speed }\end{array}$ & $R A M_{22}$ & $\begin{array}{c}1 \\
\mathrm{HD}_{2} \\
2 \\
\end{array}$ & $\boldsymbol{P r}_{22}$ \\
\hline$\cdots$ & $\ldots$ & $\ldots$ & $\cdots$ & $\ldots$ & $\cdots$ \\
\hline Cloud $_{31}$ & $\begin{array}{c}C P U \\
\text { core } 31 \\
\end{array}$ & $\begin{array}{c}\text { CPU } \\
\text { speed }\end{array}$ & $R A M_{31}$ & $\begin{array}{c}\mathrm{HD}_{3} \\
1\end{array}$ & $\boldsymbol{P r}_{31}$ \\
\hline$\ldots$ & $\ldots$ & $\ldots$ & $\ldots$ & $\ldots$ & $\ldots$ \\
\hline
\end{tabular}




\begin{tabular}{|c|c|c|c|c|c|}
\hline$\cdots$ & $\cdots$ & $\cdots$ & $\cdots$ & $\cdots$ & $\cdots$ \\
\hline Cloud $_{x y}$ & $\begin{array}{c}\text { CPU } \\
\text { core } x y\end{array}$ & $\begin{array}{c}\text { CPU } \\
\text { speed }\end{array}$ & $\boldsymbol{R A M}_{x y}$ & $\boldsymbol{H D}_{x y}$ & $\boldsymbol{P r}_{x y}$ \\
\hline
\end{tabular}

Pada masing-masing public cloud provider biasanya terdapat berbagai macam paket cloud yang dapat dipilih oleh user. Terdapat data processing unit, memory unit, storage unit, lokasi dari server, harga paket dan terdapat pula berbagai data lain seperti kapasitas bandwidth, juga custom fasilitas yang bisa dipilih oleh user dalam menggunakan fasilitas dari sebuah public cloud provider.

\subsection{Praproses Data}

Praproses data dilakukan agar data siap diolah dalam proses pengambilan keputusan menggunakan metode analytic hierarchy process (AHP). Pada data cloud provider[7][9], terdapat beberapa langkah praproses data, yaitu:

1. Penanganan missing value.

Penanganan kasus ini adalah dengan menghilangkan satu atau beberapa data public cloud provider yang mengalami missing value seperti, jika data yang didapatkan tidak mencantumkan keterangan berapa spesifikasi clock dari processing unit.

2. Keseragaman data yang diolah.

Untuk keseragaman data yang diolah, diasumsikan data yang diambil dari paket yang disediakan oleh public cloud provider adalah spesifikasi untuk penggunaan generalpurposes, dan parameter-parameter yang dipertimbangkan adalah processing unit,memory unit, storage unit, harga paket dan lokasi server.

\subsection{Pengembangan Sistem}

Secara singkat tahapan proses pengembangan sistem sebagai berikut

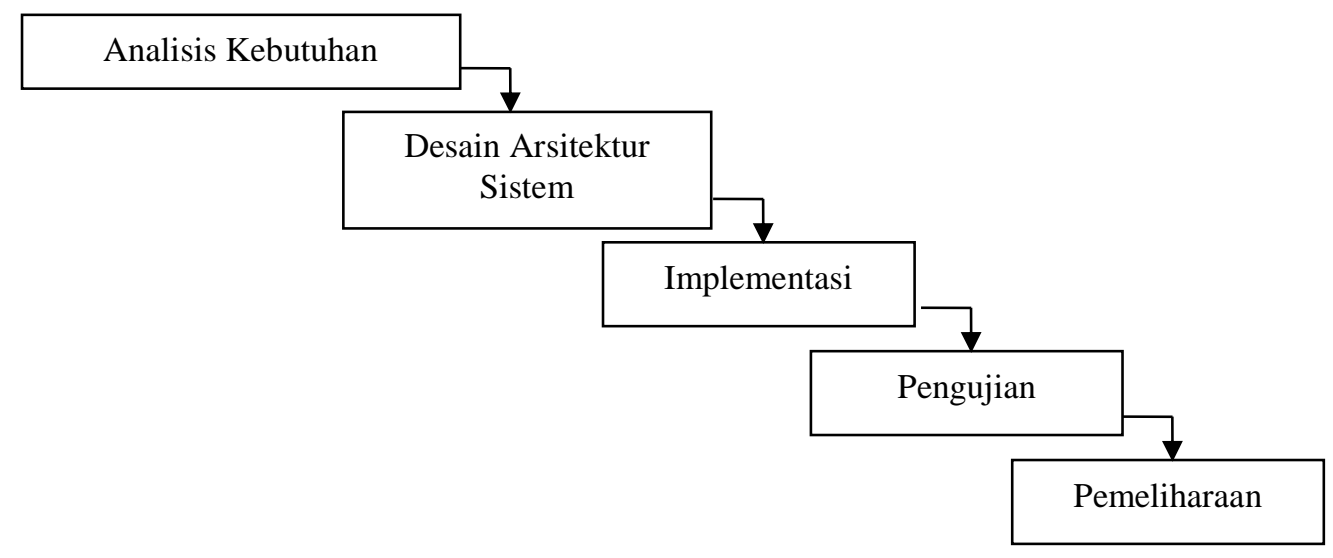

Gambar 2. Tahapan Pengembangan Sistem

2.4 Analisa Kebutuhan Fungsional Sistem

Sistem menyediakan layanan/fitur sbb:

- Aplikasi AHP dapat membaca data public cloud provider.

- Aplikasi AHP menghasilkan output rekomendasi public cloud provider terpilih.

- Private cloud dapat diimplementasikan dengan menggunakan docker.

- Sistem dapat mengakomodasi hybrid cloud yaitu menggabungkan sumber daya dari private cloud dengan public cloud terpilih. 


\subsection{Desain Arsitektur Sistem}

Proses implementasi hybrid cloud sebagai dimulai dari analisis kebutuhan sistem, selanjutnya pengumpulan data dimana akan dipilih public cloud yang terbaik untuk digunakan pada implementasi infrastruktur hybrid cloud[8]. Rancangan desain arsitektur sistem yang dapat dilihat pada Gambar 3 berikut:

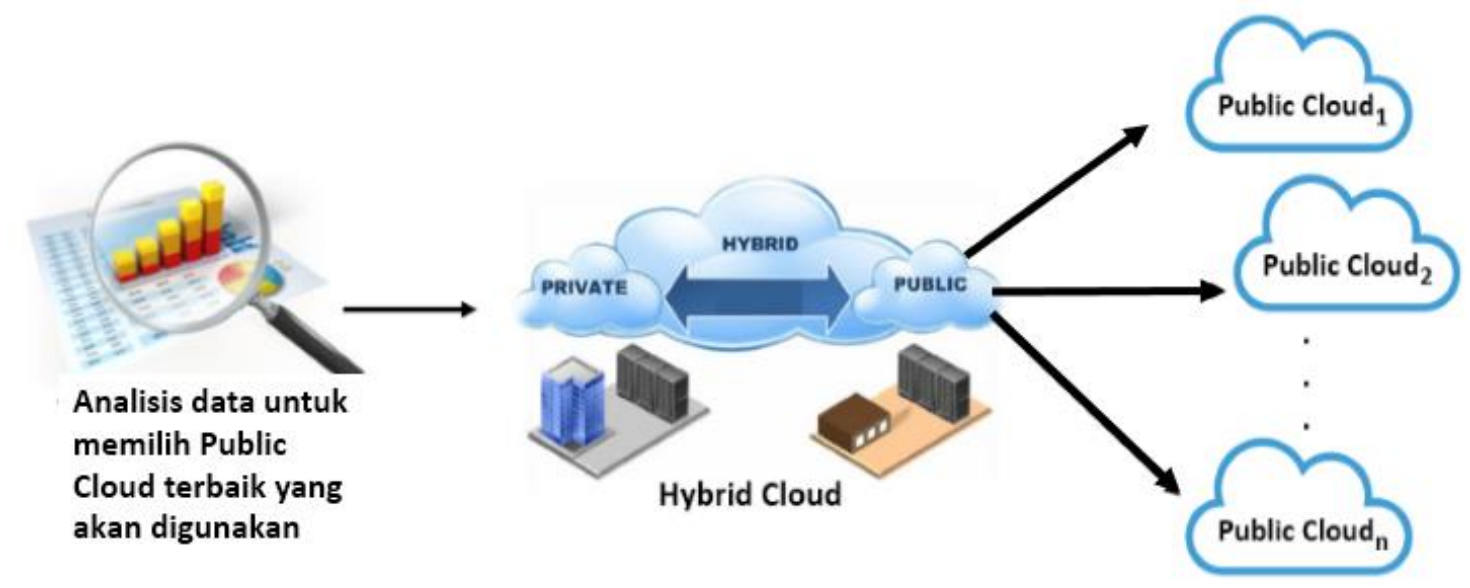

Gambar 3. Desain Arsitektur Sistem

Setelah desain arsitektur sistem dirancang, selanjutnya pengujian dan pemeliharaan sistem diterapkan supaya diperoleh sebuah aplikasi yang sesuai dengan kebutuhan.

\section{HASIL DAN PEMBAHASAN}

\subsection{Pengumpulan dan Praproses Data}

Data yang digunakan sebagai data pengujian adalah data dari public cloud provider yang diambil dari beberapa top cloud provider menurut survey yang dilakukan oleh website channele2e.com dan clutch.co(https://clutch.co/cloud dan https://www.channele2e.com/channelpartners/program/top-10-iaas-clouds-csp-reviews-rankings-amazon-azure-google-ibm/). Data cloud provider yang akan digunakan adalah data yang diambil pada bulan November 2017 seperti yang ditunjukkan pada Tabel 2 .

Tabel 2. Data Public Cloud Provider

\begin{tabular}{|c|c|c|c|c|c|c|c|c|c|}
\hline id & $\mathrm{Cp}$ & $\begin{array}{l}\text { pake } \\
\mathrm{t}\end{array}$ & proc_core & proc_speed & ram & storage & price & bandwidth & datacenter \\
\hline 1 & 1 and1 & $\begin{array}{l}\text { Cloud } \\
\text { server } \\
\text { M }\end{array}$ & 1 & 2.00 & 1.00 & 50 & 9.99 & $\begin{array}{l}300 \text { mbps up } \\
\text { and down }\end{array}$ & $\begin{array}{l}\text { USA, } \\
\text { Germany, } \\
\text { Spain }\end{array}$ \\
\hline 2 & 1and1 & $\begin{array}{l}\text { Cloud } \\
\text { server } \\
\text { L }\end{array}$ & 2 & 2.00 & 1.00 & 80 & 19.99 & $\begin{array}{l}300 \text { mbps up } \\
\text { and down }\end{array}$ & $\begin{array}{l}\text { USA, } \\
\text { Germany, } \\
\text { Spain }\end{array}$ \\
\hline & & .... & . & & & & & & \\
\hline 13 & $\begin{array}{l}\text { Digital } \\
\text { ocean }\end{array}$ & 1 & 1 & 2.00 & 0.51 & 20 & 5.00 & $1 \mathrm{~TB}$ & $\begin{array}{l}\text { New } \\
\text { York,San } \\
\text { Francisco, } \\
\text { Amsterdam } \\
\text {, Singapore, } \\
\text { London }\end{array}$ \\
\hline 14 & $\begin{array}{l}\text { Digital } \\
\text { ocean }\end{array}$ & 2 & 1 & 2.00 & 1.00 & 30 & 10.00 & $2 \mathrm{~TB}$ & $\begin{array}{l}\text { New } \\
\text { York,San } \\
\text { Francisco, } \\
\text { Amsterdam } \\
\text {, Singapore, } \\
\text { London }\end{array}$ \\
\hline
\end{tabular}




\begin{tabular}{|c|c|c|c|c|c|c|c|c|c|}
\hline 15 & $\begin{array}{l}\text { Digital } \\
\text { ocean }\end{array}$ & 3 & 2 & 2.00 & 2.00 & 40 & 2.00 & $3 \mathrm{~TB}$ & $\begin{array}{l}\text { New } \\
\text { York,San } \\
\text { Francisco, } \\
\text { Amsterdam } \\
\text {, Singapore, } \\
\text { London }\end{array}$ \\
\hline . & $\ldots$ & $\ldots \ldots$ & & & \multicolumn{2}{|c|}{.. } & & & $\ldots$ \\
\hline 53 & $\begin{array}{l}\text { IBM } \\
\text { Cloud - } \\
\text { Softlay } \\
\text { er }\end{array}$ & $\begin{array}{l}\text { B1.16x } \\
64 x 100\end{array}$ & 16 & 2.00 & 64.00 & 100 & 588.65 & $250 \mathrm{Mbps}$ & US \\
\hline
\end{tabular}

Dalam penelitian ini, jumlah parameter masukan(input) yang digunakan sebanyak 5 kandidat, yaitu processing unit(CPUcore dan CPU speed), memory unit, storage unit, dan price. Dalam penelitian ini, akan dilakukan perhitungan dari data yang sudah diambil untuk memdapatkan hasil rekomendasi public cloud provider terbaik untuk selanjutnya digabungkan dengan private cloud guna mewujudkan sebuah insfrastruktur hybrid cloud..

Langkah selanjutnya adalah praproses data yang dilakukan agar data siap diolah. Pada data terdapat beberapa langkah praproses data, yaitu:

1. Penanganan missing value adalah dengan penanganan kasus ini adalah dengan menghilangkan satu atau beberapa data public cloud provider yang mengalami missing value seperti, jika data yang didapatkan tidak mencantumkan keterangan berapa spesifikasi clock dari processing unit.

4. Sedangkan untuk keseragaman data yang diolah, diasumsikan data yang diambil dari paket yang disediakan oleh public cloud provider adalah spesifikasi untuk penggunaan generalpurposes, dan parameter-parameter yang dipertimbangkan adalah cpu core, cpu speed, memory unit, storage unit, harga paket.

\subsection{Analytic Hierarchy Process (AHP)}

Beberapa tahapan proses dalam implementasi sistem pendukung keputusan menggunakan metode AHP ini adalah : membuat matriks tabel penentuan bobot, membuat matriks tabel pair-wire comparison dan membuat matriks tabel overall composite weight. Dalam langkah-langkah penting di atas kemudian akan didapatkan pula beberapa nilai yaitu Priority Vector, Principal Eigen Value (Imax), Consistency Indeks (CI), Consistency Ratio (CR) dimana Jika nilainya kurang dari 0,1 atau $10 \%$, maka bobot yang kita berikan sudah konsisten. Pada proses pembuatan matrik tabel penentuan bobot akan didapatkan pula Nilai Pembangkit Random (RI) dimana digunakan untuk menentukan CR berdasarkan jumlah kriteria seperti pada tabel 3.

Tabel 3 Nilai Pembangkit Random (RI)

\begin{tabular}{|l|l|l|l|l|l|l|l|l|l|l|}
\hline $\mathbf{N}$ & $\mathbf{1}$ & $\mathbf{2}$ & $\mathbf{3}$ & $\mathbf{4}$ & $\mathbf{5}$ & $\mathbf{6}$ & $\mathbf{7}$ & $\mathbf{8}$ & $\mathbf{9}$ & $\mathbf{1 0}$ \\
\hline $\mathbf{R}$ & 0,00 & 0,00 & 0,58 & 0,90 & 1,12 & 1,24 & 1,32 & 1,41 & 1,45 & 1,49 \\
\hline
\end{tabular}

Pada tahap pertama penyusunan tabel penentuan bobot nilai yang dilakukan adalah mengisi cell dengan nama parameter cloud yang sama, dengan nilai 1. Kemudian matriks akan terbagi secara diagonal, kanan-atas dan kiri-bawah. Pada tahap selanjutnya isi dari tiap-tiap cell adalah hasil bagi antara kolom paling kiri dan baris paling atas. Maka tabel akan terupdate sebagai berikut.

Dalam penelitian ini diasumsikan bahwa dari kelima kriteria di atas adalah mempunyai bobot yang sama. Jika dibutuhkan untuk merubah bobot dari tiap-tiap kriterianya misal CPUspeed 2x lebih penting dari RAM maka dapat dirubah pada Sourcecode 3.1

Dalam hal ini juga dapat dihitung nilai priority vector yang merupakan Total pembagian tiap cell disebelah kiri dengan masing-masing jumlah. Lalu dibagi dengan ordo matriks (jumlah 
kriteria). Perhitungan Imax juga dapat dilakukan dengan aturan Total hasil perkalian antara jumlah masing-masing kolom dengan masing-masing Priority Vector yaitu $\operatorname{Imax}=(5 \times 0,2)+(5 \times 0,2)+(5 \times 0,2)+(5 \times 0,2)+(5 \times 0,2)$, hasilnya adalah $=5$

Tabel 4 Penentuan Bobot Nilai Akhir

\begin{tabular}{|l|c|c|c|c|c|c|}
\hline Data & $\begin{array}{c}\text { CPU } \\
\text { core }\end{array}$ & $\begin{array}{c}\text { CPU } \\
\text { speed }\end{array}$ & RAM & Storage & Harga & $\begin{array}{c}\text { Priority } \\
\text { Vector }\end{array}$ \\
\hline $\begin{array}{l}\text { CPU } \\
\text { core }\end{array}$ & 1,00 & 1,00 & 1,00 & 1,00 & 1,00 & 0,2 \\
\hline $\begin{array}{l}\text { CPU } \\
\text { speed }\end{array}$ & 1,00 & 1,00 & 1,00 & 1,00 & 1,00 & 0,2 \\
\hline RAM & 1,00 & 1,00 & 1,00 & 1,00 & 1,00 & 0,2 \\
\hline Storage & 1,00 & 1,00 & 1,00 & 1,00 & 1,00 & 0,2 \\
\hline Harga & 1,00 & 1,00 & 1,00 & 1,00 & 1,00 & 0,2 \\
\hline Jumlah & $\mathbf{5 , 0 0}$ & $\mathbf{5 , 0 0}$ & $\mathbf{5 , 0 0}$ & $\mathbf{5 , 0 0}$ & $\mathbf{5 , 0 0}$ & $\mathbf{1}$ \\
\hline & \multicolumn{7}{|c|}{ Principal Eigen Value (Imax) } \\
\hline \multicolumn{7}{|c|}{ Concistency Index (CI) } \\
\hline \multicolumn{7}{|c|}{} \\
\hline
\end{tabular}

Rumus untuk perhitungan $C I=(\operatorname{Imax}-$ jumlah kriteria $) /($ jumlah kriteria -1$)$ sehingga diperoleh nilai $\mathrm{CI}=0$. Dan terakhir adalah hitung $\mathrm{CR}=\mathrm{CI} / \mathrm{RI}$, Jika $\mathrm{CR}>10 \%$, maka tabel bobot harus diperbaiki. Didapatkan nilai $\mathrm{CR}=0 / 1,12=0$. Sehingga jika diupdate matriksnya dengan kondisi matriks yang sekarang adalah seperti ditunjukan pada table 4.

3.3 Analytic Hierarchy Process (AHP) - Pair Wise Comparison

Tabel 5 Overall Composite Weight

\begin{tabular}{|l|c|c|c|c|c|}
\hline Overall Composite & Weight & CP1 & CP2 & $\ldots \ldots$ & CPx \\
\hline Processing_Core & 0.2 & $\begin{array}{c}0.002906976744 \\
1860465\end{array}$ & $\begin{array}{c}0.0019346850 \\
332765816\end{array}$ & $\ldots$ & $\begin{array}{c}0.005813953488 \\
372093 \\
\text { Processing_Speed }\end{array}$ \\
\hline RAM & 0.2 & $\begin{array}{c}0.005813953488 \\
372093\end{array}$ & $\begin{array}{c}0.0038693700 \\
66553163\end{array}$ & $\ldots$ & $\begin{array}{c}0.006653174073 \\
7409435\end{array}$ \\
\hline Storage & 0.2 & $\ldots$ & $\ldots$ & $\ldots$ \\
\hline Price & 0.2 & $\ldots$ & $\ldots$ & $\ldots$ \\
\hline
\end{tabular}

Dari penyusunan matrix pada masing-masing parameter tersebut akan dihasilkan sebuah composite weights seperti pada tabel 5, yang digunakan untuk menentukan bobot dari masingmasing public cloud provider yang sudah ada dalam database, nilai ini nantinya digunakan untuk pemeringkatan prioritas public cloud provider yang disarankan untuk digunakan berdasarkan metode AHP yang diimplementasikan. 
3.4 Implementasi Analytic Hierarchy Process dalam Bahasa Java

Untuk melihat hasil dari analisis AHP maka diimplementasikan dalam bahasa pemrograman Java. Berikut ini merupakan source code yang digunakan untuk pengujian sistem pendukung keputusan AHP:

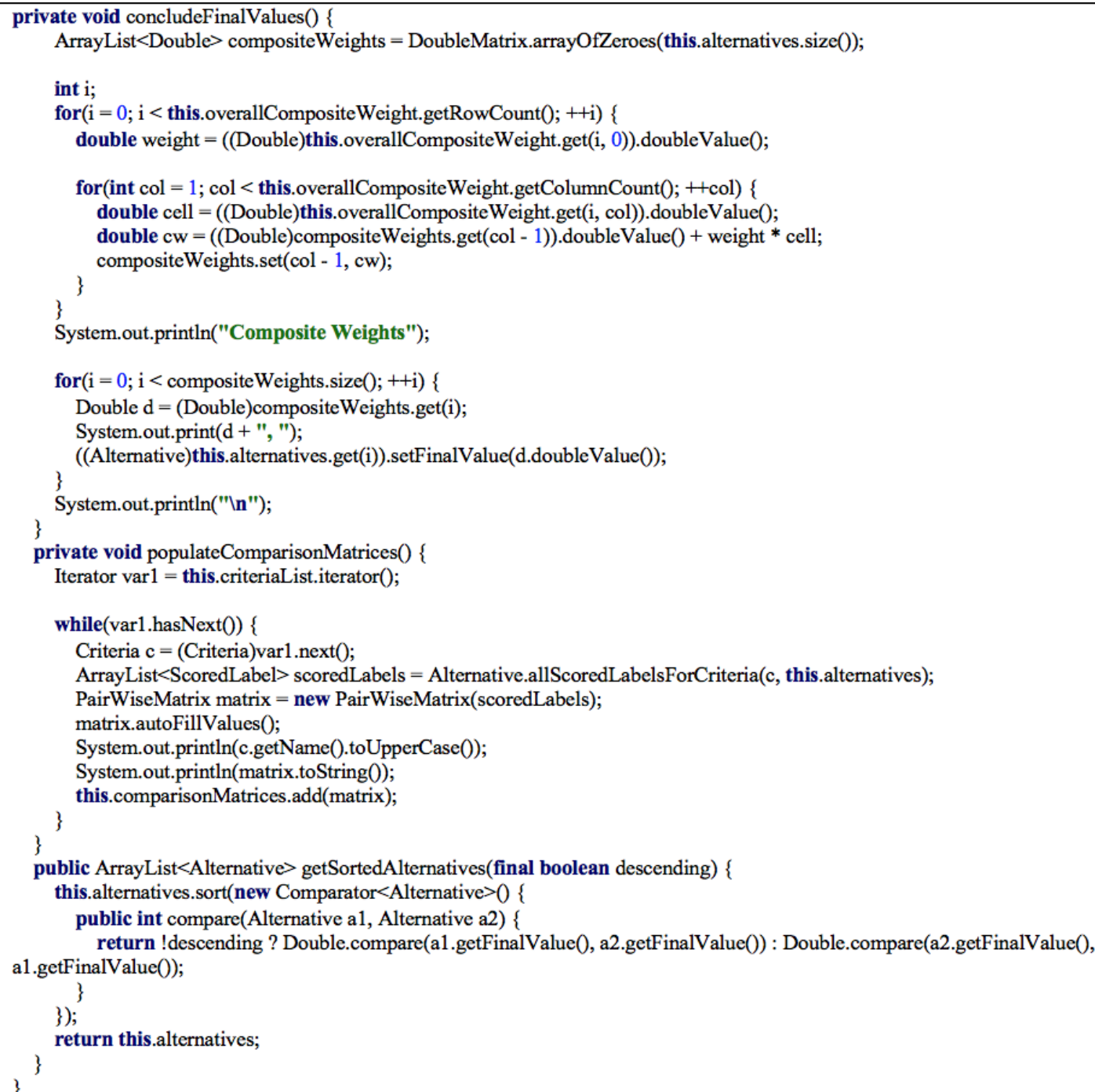

Gambar 4. Source Code Perhitungan final dan hasil AHP

\subsection{Pengujian Sistem}

Pada pengujian sistem, setelah diperoleh informasi public cloud yang terpilih maka tahapan selanjutnya akan dilakukan untuk implementasi hybrid cloud yaitu menggabungkan sumber daya dari private cloud dan sumber daya dari public cloud terpilih menggunakan docker swarm.

\section{Pengujian Aplikasi Desktop}

Pengujian aplikasi desktop dilakukan melalui Intellij IDEA untuk mendapatkan hasil analisis public cloud yang terpilih untuk digunakan dan digabungkan dengan sumber daya private cloud. Berikut tampilan dan pengujian aplikasi desktop AHP 


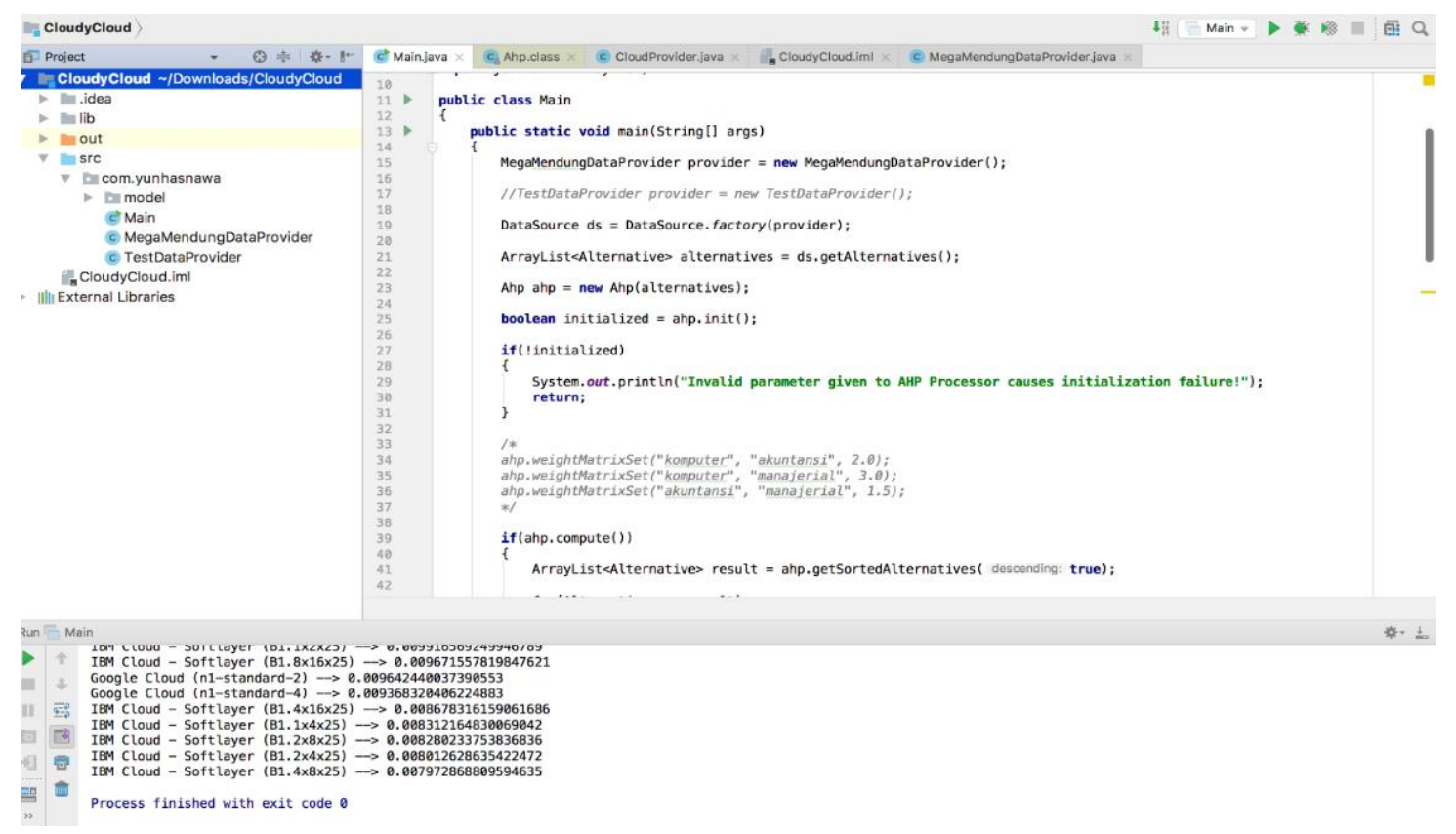

\section{Gambar 5. Aplikasi Desktop AHP}

Berikut hasil analisis dari program AHP yang telah diimplementasikan menggunakan java. Pada tahap awal ditampilkan hasil dari matriks dimana dari 5 parameter yang dipertimbangkan yaitu processing core, processing speed, memory, storage dan harga diasumsikan semua mempunyai bobot yang sama pentingnya. Selanjutnya merupakan matrix dari masing-masing parameter yang dipertimbangkan yaitu matriks processing_core seperti yang ditampilkan pada gambar 6 dan price pada gambar 7sebagai berikut.

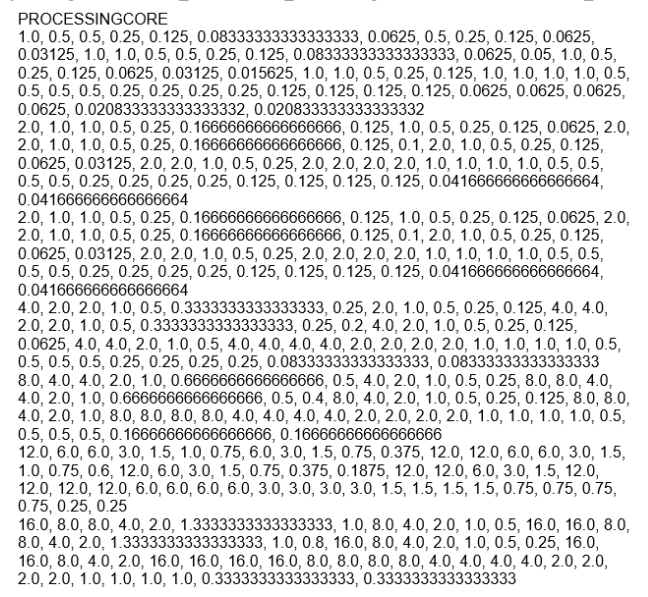

Gambar 6.Matrix Parameter processing Core

\begin{abstract}
1.0, 2.0010010010010006, 3.0020020020020017, 5.0040040040040035, 13.012012012012013, 24.924924924924927, 35.03403403403403, $2.8028028028028027,5.605605605605605,11.21121121121121$, $22.42242242242242,44.84484484484484,0.5005005005005004$, $1.0010010010010009,2.0020020020020017,4.0040040040040035$, $8.008008008008007,16.016016016016014,32.03203203203203$,
$48.048048048048045,64.06406406406406,2.429429429429429$, 4.859859859859859, $9.70970970970971,19.41941941941942,38.83883883883884$ $77.67767767767768,155.45545545545545,1.3413413413413413$ 1.7137137137137135, 5.883883883883883, 13.108108108108107, 26.215215215215213, 3.5205205205205203, 3.5205205205205203 $5.513513513513513,5.513513513513513,6.974974974974975,6.974974974974975$, 7.439439439439438, 7.439439439439438, 13.35235235235235, 13.35235235235235, 15.013013013013012, 15.013013013013012, 26.041041041041037 $26.041041041041037,32.086086086086084,32.086086086086084$,
476966966966967,47 $47.6966966966967,47.6966966966967,58.923923923923915,58.923$
$146.94394394394394,146.94394394394394$ $146.94394394394394,146.94394394394394$
$0.4997498749374688,1.0,1.5002501250625313,2.500750375187594$ $6.502751375687845,12.45622811405703,17.508254127063534$ 1.4007003501750876, 2.8014007003501753, 5.602801400700351, $11.205602801400701,22.411205602801402,0.25012506253126565$
$0.5002501250625313,1.0005002501250626,2.001000500250125$ $0.5002501250625313,1.0005002501250626,2.001000500250125$,
$4.00200100050025,8.0040020010005,16.008004002001,24.012006003001503$ $4.00200100050025,8.0040020010005,16.008004002001,24.012006003001503$,
$32.016008004002,1.2141070535267635,2.428714357178589,4.852426213106554$ $32.016008004002,1.2141070535267635,2.428714357178589,4.8524$
$9.704852426213108,19.409704852426216,38.81940970485243, \mid$
\end{abstract}

\section{Gambar 7. Matrix Parameter Price}

Hasil dari matrix parameter yang lain yaitu processing speed, memory, storage dan price. Pada laporan ini hanya ditampilkan sebagian yaitu sebagai contoh pada gambar 7 ditampilan matrix untuk parameter price dari public cloud provider. Dari penyusunan matrix pada masing-masing parameter tersebut akan dihasilkan sebuah composite weights yang digunakan untuk menentukan bobot dari masing-masing public cloud provider yang sudah ada dalam database, nilai ini nantinya digunakan untuk pemeringkatan prioritas public cloud provider yang disarankan untuk digunakan berdasarkan metode AHP yang diimplementasikan. 


\begin{abstract}
Composite Weights
$0.02402907476818176,0.01691594217271036,0.015675522799064916$,

$0.016577679780148825,0.020932536904668304,0.029701000454057918$, $0.039583058184953564,0.014916291352855264,0.016123972137759384$, $0.02310015211332731,0.039429655519006845,0.0406658458905785$, $0.02334464099661628,0.015578169285151428,0.012194438509991884$, $0.01257910266340284,0.01800976513991923,0.02820950911578374$, $0.038779030962355056,0.04944099727660305,0.013440624567445315$, $0.011090132143224327,0.011877876934338102,0.016190571560327275$, $0.02618833229121743,0.04687003949245365,0.019032443119182896$, $0.017014407667690395,0.011253057657632218,0.013428794792894017$, $0.02043096727878588,0.010668831736515257,0.013168831736515256$ $0.009231507150205117,0.011731507150205118,0.009137701716589688$, $0.011637701716589687,0.009752543081179904,0.012252543081179902$, $0.00985773692057693,0.012357736920576928,0.011258297111642307$, $0.013758297111642306,0.013082704746861927,0.015582704746861926$ $0.016049659963705817,0.018549659963705816,0.020519592161785557$, $0.02301959216178556,0.026639608644773435,0.029139608644773437$,
\end{abstract}

Gambar 8. Composite Weights

Berdasarkan composite weights diatas hasil akhir dari analisis AHP yang sudah diimplementasikan menggunakan java ini adalah rekomendasi pemilihan public cloud yang dapat dipilih untuk implementasi hybrid cloud. Dari hasil analisis, diperoleh sumber daya public cloud yang terpilih adalah public cloud Digital Ocean, berdasarkan rekomendasi ini maka untuk tahap pengujian selanjutnya akan dibangun hybrid cloud dengan menggabungkan sumber daya dari private dan sumber daya dari public cloud Digital Ocean. Hasil akhir dari analisis AHP dapat dilihat pada gambar 9

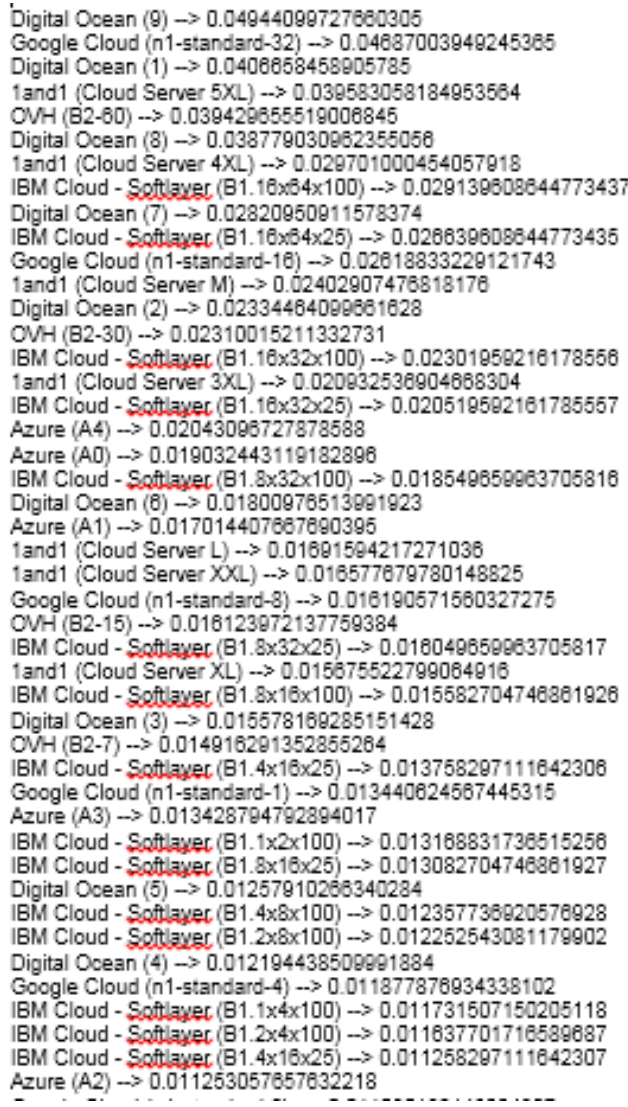

Gambar 9. Rekomendasi Public Cloud 


\section{KESIMPULAN}

Dari hasil yang diperoleh dapat diambil beberapa kesimpulan yakni sebagai berikut:

1. Telah dilakukan uji coba implementasi Analytic Hierarchy Process (AHP) menggunakan bahasa pemrograman Javab. Pada percobaan tersebut rekomendasi public cloud terpilih yang dapat diimplementasikan dalam infrastruktur hybrid cloud.

2. Aplikasi Desktop AHP telah dibangun menggunakan perangkat lunak xampp, mysql, Intellij IDEA.

3. Implementasi Hybrid Cloud memanfaatkan teknologi Docker yang diimplementasikan dalam container-container.

\section{SARAN}

Untuk penelitian selanjutnya, diharapkan penelitian ini dapat diselesaikan dengan mengimplementasikan platform big data seperti Hadoop untuk menguji hybrid cloud yang dibuat. Di sisi lain, diharapkan topik penelitian ini dikembangkan dengan membandingkan metode yang dibuat dengan system pendukung keputusan menggunakan metode lainnya dll.

\section{UCAPAN TERIMA KASIH}

Penulis mengucapkan terima kasih kepada P3M Politeknik Kediri yang telah memberi dukungan pendanaan terhadap penelitian ini.

\section{DAFTAR PUSTAKA}

[1] Ginting, A.A., Virgono A., Irawan, B. 2013. Perancangan Dan Implementasi Server Untuk Sistem Komputasi Awan Di Intranet Kampus Institut Teknologi Telkom: Seminar Nasional Informatika UPN "Veteran" Yogyakarta

[2] Ariani, N.K.P.A., Sunarya I.M.G., Wirawan, I.M.A. 2016. Pengembangan Sistem Pendukung Keputusan Dengan Metode Analytic Hierarchy Process (AHP) Untuk Memberikan Rekomendasi Properti Di Kabupaten Buleleng: Kumpulan Artikel Mahasiswa Pendidikan Teknik Informatika (KARMAPATI)

[3] Maghfiroh, S., Irawan, M. I. 2016. Perancangan dan Implementasi Perangkat Lunak Sistem Pendukung Keputusan Multi Kriteria Menggunakan Metode AHP: JURNAL SAINS DAN SENI ITS Vol. 5 No. 2

[4] Song, Li. et al. 2015. Towards Operational Cost Minimization in Hybrid Clouds for Dynamic Resource Provisioning with Delay-Aware Optimization: IEEE Transactions On Services Computing, Vol. 8, No. 3.

[5] Mell, P., Grance, T. 2011. The NIST Definition of Cloud Computing: National Institute of Standards and Technology.

[6] Kusuma, IGNA 2017. Survei: Aplikasi dan Pengembangan Model Software-as-a- Service pada Cloud Computing: Jurnal Sistem dan Informatika Vol. 12 No.1

[7] Prabowo, W. S., Muslim, M. H., Iryanto, S.B. 2015. Pusat Data Privat Virtual Pemerintah Berbasis Komputasi Awan (Studi Empiris Pada Lembaga Ilmu Pengetahuan Indonesia).

[8] Arora, R. 2015, Creating a Multinode Hadoop cluster in 4 mins using docker containers. http://events.linuxfoundation.org/sites/events/files/slides/Presentation_Rachit_ContainerCo n.pdf diakses 27 Mei 2017.

[9] Tutang. 2014. Sistem Operasi Cloud Computing Dengan Windows Azure: Andi Publisher.

[10]Kusumadewi. S, dkk. 2006. Fuzzy Multi-Attribute Decision Making (Fuzzy MADM): Graha Ilmu. 